\section{The public production of medicines compared to the National Policy of Medicines and the burden of disease in Brazil}

\author{
A produção pública de medicamentos frente à \\ Política Nacional de Medicamentos e à carga \\ de doenças no Brasil
}

\section{La producción pública de medicamentos frente a la Política Nacional de Medicamentos y a la carga de enfermedades en Brasil}

\begin{abstract}
The public production of medicines in Brazil by Government Pharmaceutical Laboratories has once again become the object of incentives, and Industrial Development Partnerships are one of the mechanisms adopted for the production of strategic medicines for the Brazilian Unified National Health System (SUS). Considering that burden-of-disease studies have been used as a tool to define priority and essential medicines, the article compares the product portfolios of the country's Official Pharmaceutical Laboratories (OPL) and the list of strategic medicines for the SUS and burden of disease in Brazil in 2008. Of the 205 strategic medicines for the SUS and 111 from the portfolios, 73\% and 89\%, respectively, are on the National List of Essential Medicines (RENAME 2014). Some strategic medicines for the SUS are already produced by OPL and feature the selection of cancer drugs and biologicals. The current study contributes to the discussion on the public production of medicines in light of the country's current industrial policy and highlights the need to define priority drugs and the role of OPL in guaranteeing access to them.
\end{abstract}

Burden of Disease; Disabilty-adjusted Life Years; Drug Industry; Pharmaceutical Services
Tatiana Aragão Figueiredo 1

Joyce Mendes de Andrade Schramm 2

Vera Lúcia Edais Pepe 2

doi: 10.1590/0102-311X00179815

\author{
Correspondence \\ T. A. Figueiredo \\ Instituto de Tecnologia em Fármacos, Fundação Oswaldo Cruz \\ Av. Comandante Guaranys 447, Rio de Janeiro, RJ \\ 22775-903, Brasil. \\ tatiana.figueiredo@far.fiocruz.br \\ 1 Instituto de Tecnologia em Fármacos, Fundação Oswaldo \\ Cruz, Rio de Janeiro, Brasil. \\ 2 Escola Nacional de Saúde Pública Sergio Arouca \\ Fundação Oswaldo Cruz, Rio de Janeiro, Brasil.
}




\section{Introduction}

The National Policy of Medicines, in Brazil, is concerned with the public production of medicines, especially those from the Brazilian Essential Medicines List (RENAME), in order to ensure adequate access to necessary medicines for the general population ${ }^{1}$. Regarding the production of medicines, Brazil notably uses both private production and public production by official state and federal laboratories.

Official Pharmaceutical Laboratories (OPL) are located in all regions of Brazil with most belonging to the Association of Official Pharmaceutical Laboratories of Brazil (ALFOB), which aims to be a collective management tool for all associated laboratories 2 . The majority of public laboratories have an undiversified portfolio, focusing on lower-cost medicines; therefore supporting national health policies to combat and control diseases, promoting access to medicines and attempting to meet the demands of the Ministry of Health and Public Health Secretariats 2,3.

Brazil has a long history of investments in the self-sufficient public production of priority vaccines and medicines for the Brazilian Unified National Health System (SUS). In 1971, the Center of Medicines (CEME) was the first initiative to establish a National Medicines Policy, involving public and private production to promote access to essential medicines. CEME had an important coordinating role with the network of OPL, controlling their production and distribution. CEME was extinguished in 1990 and, despite the efforts of the Ministry of Health, the OPL were left without a coordinator. In relation to production capacity, although these laboratories received financial investments for modernization and expansion, they are still inferior to the private sector in technology, processes and products 2,4 .

The prioritization of industrial policy in the 2007 government agenda resulted in the inclusion of the Health Economic-Industrial Complex as a planning component of the Ministry of Health. The public production of medicines becomes the subject of incentives including Partnership for Productive Development (PDP) 5,6. PDP are defined as partnerships that involve cooperation, through an agreement, between public institutions and private entities. This agreement serves to enhance the development, transfer and absorption of technology therefore contributing to improvements in both productivity and technological capacity of the country and the production of strategic products to meet the demands of the SUS 7. In addition to the transfer of technology for medicines, there is also the transfer of active pharmaceutical ingredients 8 .

A list of strategic medicines for the SUS was prepared in order to set priorities for the PDP project proposals. Strategic medicines for the SUS are defined as those necessary for health promotion, prevention and recovery, with either centralized acquisitions or the capacity for centralization by the Ministry of Health. The SUS strategic medicines list must set annual priorities for the submission of PDP project proposals. The selection of strategic medicines should consider: (1) the importance of the medicine to the SUS, according to policies and programs of health promotion, prevention and recovery; (2) centralized acquisition of the medicine by the Ministry of Health, or the possibility of centralization; and (3) interest in the national production of the medicine and active pharmaceutical ingredients relevant to the Health Economic-Industrial Complex. One should additionally consider the high purchase price for the SUS, the import dependency for health care within the context of the SUS for the previous three years, recent medicines incorporated by the SUS and the possibility of it being a neglected medicine with potential shortage risks 8 .

Although the law defines the criteria considered in the selection of strategic medicines for the SUS, the methodology is still unclear. Furthermore, burden of disease information (disability adjusted life years - DALY) has been used internationally as a tool to define the priority medicines for research and development, technological incorporation, and selection of essential medicines 9,10,11,12,13,14,15,16.

This paper aims to analyze both OPL medicines portfolios and the list of medicines considered strategic for public production in relation to the burden of disease in Brazil. 


\section{Methods}

This exploratory study compares the medicine profile of OPL portfolios and those considered strategic for public production to an epidemiological profile, with geographical mapping, by the study on burden of disease in Brazil from 200817.

\section{Data source}

Two data sources were used for medicine identification: (1) The OPL medicines portfolio and (2) the list of strategic medicines for the SUS (Ordinance MS/GM 3,089/2013 and Ordinance MS/GM 2,888/2014). Thirteen OPL, among the seventeen operating, according to the ALFOB (Laboratórios associados. http://www.alfob.org/portugues/site/laboratorios, accessed on 07/Apr/2015), were selected, because their online electronic portfolios were available on June 20th 2015.

The Brazilian Burden of Disease Study from 2008 was used to identify the most relevant causes of disease. Burden of Disease studies estimate the DALY indicator from the sum of two fractions: years of life lost (YLL) and years lived with disability (YLD) 17. This paper considered 85 DALY causes based on the Brazilian Burden of Disease Study from 2008.

In the 2008 Brazilian Burden of Disease Study, diseases and injuries were classified into three large groups: (1) communicable maternal, neonatal, and nutritional disorders; (2) noncommunicable diseases; and (3) external causes 17. Each large group was divided into disease subgroups. For example, the communicable diseases group comprises 14 subgroups, including malignant neoplasms and diabetes mellitus. Furthermore, these disease groups were subdivided by specificity of disease. For example, there were 17 types of "malignant neoplasms" cancer, classified through the $10^{\text {th }}$ revision of the International Classification of Diseases (ICD-10).

However, the DALY calculation was not used for all existing diseases within subgroups. For example, sexually transmitted diseases were not considered in their entirety in the $2008 \mathrm{Brazil}$ ian Burden of Disease Study, either due to lack of information about the incidence parameters for chlamydia, gonococci infection and syphilis or a low mortality and morbidity tax. Only congenital syphilis was estimated while the other sexually transmitted diseases were included in residual group category I.A, composed of infectious and parasitic diseases. Other diseases in residual group category I.A included: cholera, pertussis, acute poliomyelitis, diphtheria, measles and neonatal tetanus 17 .

This study did not consider the infectious and non-infectious residual categories. Congenital anomalies and external causes were excluded due to the impossibility of assigning them specific medicines. Conditions treated surgically and/or with no specific medicine, such as low birth weight, cataracts, obstructed labour, appendicitis, choking and birth trauma, were also excluded.

\section{Analysis plan}

Medicines were classified according to their Anatomical Therapeutic Chemical (ATC) classification 18. Medicines that had no ATC were excluded, as well as herbal medicines, diagnostic tests, and those without a corresponding specific DALY cause, such as medicines for anaesthesia, dilution vehicles, antidotes, medicines for contraception, medicines for hydration or medicines for palliative treatment.

Analyses were carried out based on the medicines and their ATC classifications due to only portfolios having medicine dosage forms.

Medicines were correlated with the main therapeutic indications, considering: (1) ATC classification; (2) clinical indications described in Ordinance MS/GM 3,089/2013 and Ordinance MS/GM 2,888/2014; (3) Brazilian National Formulary (FTN) clinical indications of the RENAME; (4) the Brazilian Health Regulatory Agency (Anvisa) and; (4) Clinical indications of the Ministry of Health's Clinical Protocols and Therapeutic Guidelines (PCDT). Finally, if in doubt, an expert was consulted.

Clinical indications were classified according to ICD-10 and then associated to the causes of diseases described in the Brazilian Burden of Disease Study from 2008.

In some cases, Ordinance MS/GM 3,089/2013 and Ordinance MS/GM 2,888/2014 did not describe exactly the active substance's name, as in the case of statins, only referring to the type of medicine, 
"statins", without specifying the active substance. In these cases, the medicines present in RENAME 2014 were used as a proxy of the therapeutic class.

Medicines present in the OPL portfolios, as well as both Ordinance MS/GM 3,089/2013 and Ordinance MS/GM 2,888/2014 were compared with RENAME 2014 and lists from the Pharmaceutical Services Financing Component.

\section{Results and discussion}

There were 204 strategic medicines for the SUS and 73\% (149) of them had been selected for RENAME 2014. The majority of the medicines which hadn't been selected for RENAME were antineoplastic (61\%), monoclonal antibodies (9\%) and others including enzymes, antiretrovirals, medicines for pulmonary hypertension, hormones, immunosuppressants and proteins. The OPL portfolios added up to 111 medicines, containing 99 (89\%) from RENAME 2014, and the remaining (11\%) had been present in earlier versions of RENAME. Anti-infective for systemic use was the most frequent group (27.9\%), followed by alimentary tract and metabolism (15.3\%) and nervous system (13.5\%). Among the strategic medicines, Antineoplastic and Immunomodulating Agents stood out as the main group (35.8\%), followed by anti-infective for systemic use (26.5\%) and nervous system (8.8\%) (Table 1).

Antineoplastic and immunomodulating agents in the list of strategic medicines for the sus were divided into monoclonal antibodies, interferons and TNF- $\alpha$ inhibitors.

Most of the OPL production (64\%) focuses on the basic pharmaceutical services component, 29\% on the strategic component and $7 \%$ on the specialized component. In contrast, most of the strategic medicines for the SUS belong to the specialized component (58\%) while the basic component corresponds to the smallest portion (13\%).

Of the 111 medicines presented in the OPL portfolio, 25 (23\%) were also in the list of strategic medicines for the SUS and are part of RENAME 2014, containing 64\% of the strategic component and $36 \%$ of the basic component. Table 2 shows that $68 \%$ of them are manufactured by more than one OPL.

Table 1

Number and percentage of medicines according to the 1st level of Anatomical Therapeutic Chemical (ATC) classification 18 in Official Pharmaceutical Laboratories (OPL) portfolio and the strategic medicines list for the Brazilian Unified National Health System (SUS; Ordinance MS/GM 3,089/2013 and Ordinance MS/GM 2,888/2014).

\begin{tabular}{|c|c|c|c|c|}
\hline \multirow[t]{2}{*}{ ATC classification (1st level) } & \multicolumn{2}{|c|}{ OPL } & \multicolumn{2}{|c|}{ Strategic medicines } \\
\hline & $\mathbf{n}$ & $\%$ & $\mathbf{n}$ & $\%$ \\
\hline A - Alimentary tract and metabolism & 17 & 15.3 & 13 & 6.4 \\
\hline B - Blood and blood forming organs & 4 & 3.6 & 3 & 1.5 \\
\hline C - Cardiovascular system & 10 & 9.0 & 10 & 4.9 \\
\hline D - Dermatological & 5 & 4.5 & 1 & 0.5 \\
\hline G - Genitourinary system and sex hormones & 0 & 0.0 & 3 & 1.5 \\
\hline H - Systemic hormonal preparations (exclusive sex hormones and insulins) & 4 & 3.6 & 8 & 3.9 \\
\hline J - Anti-infective for systemic use & 32 & 28.8 & 54 & 26.5 \\
\hline L - Antineoplastic and immunomodulating agents & 3 & 2.7 & 73 & 35.8 \\
\hline M - Musculoskeletal system & 4 & 3.6 & 1 & 0.5 \\
\hline N - Nervous system & 15 & 13.5 & 18 & 8.8 \\
\hline P - Antiparasitic products, insecticides and repellents & 9 & 8.1 & 11 & 5.4 \\
\hline R - Respiratory system & 7 & 6.3 & 7 & 3.4 \\
\hline V-Various & 1 & 0.9 & 2 & 1.0 \\
\hline Total & 111 & 100.0 & 204 & 100.0 \\
\hline
\end{tabular}




\section{Table 2}

Medicines of the Official Pharmaceutical Laboratories (OPL) portfolio and the strategic medicines list for the Brazilian Unified National Health System (SUS; Ordinance MS/GM 3,089/2013 and Ordinance MS/GM 2,888/2014) according to the therapeutic indication and number of public producers.

\begin{tabular}{|c|c|c|}
\hline Medicines & Therapeutic indications * & Number of public producers \\
\hline Captopril & Antihypertensive & 6 \\
\hline Amoxiciline & Antibiotic & 4 \\
\hline Cefalexin & Antibiotic & 4 \\
\hline Ethambutol & Antibiotic (tuberculosis/leprosy) & 4 \\
\hline Lamivudine & Antiretroviral & 4 \\
\hline Zidovudine & Antiretroviral & 4 \\
\hline Folic Acid & Antianemic & 3 \\
\hline Nevirapin & Antiretroviral & 3 \\
\hline Penicillin G potassium & Antibiotic & 3 \\
\hline Prednisone & Antiasthmatic & 3 \\
\hline Benzathine benzylpenicillin & Antibiotic & 2 \\
\hline Chloroquine & Antimalarial & 2 \\
\hline Dapsone & Antibiotic (tuberculosis/leprosy) & 2 \\
\hline Ethionamide & Antibiotic (tuberculosis/leprosy) & 2 \\
\hline Mefloquine & Antimalarial & 2 \\
\hline Penicillin G potassium and procaine & Antibiotic & 2 \\
\hline Primaquin & Antimalarial & 2 \\
\hline Artesunate & Antimalarial & 1 \\
\hline Diethylcarbamazine & Antinematodal & 1 \\
\hline Doxycycline & Antibiotic & 1 \\
\hline Efavirenz & Antiretroviral & 1 \\
\hline Isoniazid & Antibiotic (tuberculosis/leprosy) & 1 \\
\hline Meglumine antimoniate & Antiprotozoal (leishmaniasis) & 1 \\
\hline Ofloxacine & Antibiotic & 1 \\
\hline Streptomycin & Antibiotic & 1 \\
\hline
\end{tabular}

* Therapeutic indication according to the Anatomical Therapeutic Chemical (ATC) classification 18.

The list of strategic medicines for the SUS defines priorities for the PDP projects. Table 2 shows that $23 \%$ of medicines selected as strategic for the SUS are already produced by one or more OPL. Although OPL already produce some strategic medicines for the SUS, for some of them, the production of the active pharmaceutical ingredient cannot be consolidated in the country, thus the drug becomes strategic for public production, and therefore a future PDP. After all, the PDP also predicts the transfer of active pharmaceutical ingredients. What remains to be further analyzed is which active pharmaceutical ingredients, of the 25 medicines already produced by OPL, requires technology transfer. This is not within the scope of this work, but certainly there will be benefits in conducting this analysis, given that the list contains a variety of medicines, including those for neglected diseases, with non-significant international interest and which therefore are initial candidates for technology transfer. As an example it could be mentioned that the difficulty in the acquisition of active pharmaceutical ingredients that are produced outside of Brazil affected the supply of benzamine penicillin in 2015 and thus, affected the treatment of syphilis, especially congenital syphilis 19,20. Moreover, captopril, for example, is produced by six OPL and other private entities such as generic medicine industries, therefore it is difficult to understand why this medicine was selected as strategic and a future PDP.

It was possible to identify the causes of the Brazilian burden of disease's DALY, and compare them to the list of strategic medicines for the SUS: $35 \%$ refer to Group I - communicable maternal, neonatal, and nutritional disorders and $65 \%$ to Group II - non-communicable diseases. A comparison was 
possible for 92 medicines, of the 111 produced by OPL, most of which (66.6\%) were designed for the treatment of Group II diseases.

Table 3 shows that the list of strategic medicines for the SUS is similar to what is currently being produced by OPL, the majority being for infectious and parasitic diseases. This includes medicines for HIV/AIDS, malaria, Chagas disease, leishmaniosis, tuberculosis, leprosy, hepatitis B and C, filariasis, Rocky Mountain spotted fever, systemic mycoses, respiratory infections, nutritional deficiencies and maternal conditions (e.g., maternal sepsis). However, for other important causes of DALY, such as psychiatric and cardiovascular diseases, the strategic medicines list developed and proposed for the SUS does not seem to be sufficient. In the list of strategic medicines for the SUS, another point worth mentioning is the large number of medicines selected for the treatment of cancer and musculoskeletal diseases.

The list of strategic medicines for the SUS and the OPL medicine portfolios do not have medicines for nine Brazilian burden of disease causes of DALY: unintentional external causes (position 6 on Brazilian burden of disease causes), intentional external causes (position 9 on Brazilian burden of disease causes), congenital anomalies (position 17 on Brazilian burden of disease causes), oral conditions (position 18 on Brazilian burden of disease causes), sense organs disorders (position 19 on Brazilian burden of disease causes) and benign neoplasms (position 20 on Brazilian burden of disease causes) (Table 3). The absence of medicines for these causes of DALY is justifiable, since there is no specific medicine for treatment or they are surgically treated.

OPL play an important role in the production of medicines used to treat neglected diseases in addition to meeting the demands of the Ministry of Health, due to the low interest of private entities 19,20. A significant number of medicines for infectious and parasitic diseases are part of the list of strategic medicines for the SUS, because the selection criteria for this list includes medicines for neglected diseases and the potential danger of shortages 7 .

Table 3

Number of medicines of the Official Pharmaceutical Laboratories (OPL) portfolio, strategic medicines list for the Brazilian Unified National Health System (SUS; Ordinance MS/GM 3,089/2013 and Ordinance MS/GM 2,888/2014) and Brazilian Burden of Disease Study 17 (disability adjusted life years - DALY x 10,000 inhabitants).

\begin{tabular}{|c|c|c|c|c|c|c|}
\hline \multirow[t]{2}{*}{ DALY causes } & \multicolumn{2}{|c|}{ OPL } & \multicolumn{2}{|c|}{ Strategic medicines } & \multirow[t]{2}{*}{ DALY $\times 10,000$} & \multirow{2}{*}{$\begin{array}{c}\text { Position on Brazilian Burden of } \\
\text { Disease Study (2008) }\end{array}$} \\
\hline & $\mathbf{n}$ & $\%$ & $\mathbf{n}$ & $\%$ & & \\
\hline \multicolumn{7}{|l|}{$\begin{array}{l}\text { Communicable maternal, neonatal, and } \\
\text { nutritional disorders }\end{array}$} \\
\hline Infectious and parasitic diseases & 36 & 39.1 & 62 & 31.0 & 17.9 & 7 \\
\hline Neonatal conditions & 1 & 16.7 & 2 & 1.0 & 12.7 & 10 \\
\hline Respiratory infections & 2 & 2.2 & 6 & 3.0 & 11.7 & 12 \\
\hline Nutritional deficiencies & 1 & 16.7 & 1 & 0.5 & 5.6 & 16 \\
\hline Maternal conditions & 1 & 1.1 & 1 & 0.5 & 1.2 & 21 \\
\hline \multicolumn{7}{|l|}{ Noncommunicable diseases } \\
\hline Mental and behavioral disorders & 4 & 4.3 & 4 & 2.0 & 73.0 & 1 \\
\hline Cardiovascular diseases & 12 & 13.0 & 6 & 3.0 & 56.6 & 2 \\
\hline Malignant neoplasms & 0 & 0.0 & 43 & 21.5 & 32.6 & 3 \\
\hline Respiratory diseases & 5 & 5.4 & 8 & 4.0 & 30.7 & 4 \\
\hline Neurological conditions & 7 & 7.6 & 17 & 8.5 & 29.9 & 5 \\
\hline Diabetes mellitus & 2 & 2.2 & 2 & 1.0 & 17.5 & 8 \\
\hline Digestive diseases & 4 & 4.3 & 5 & 2.5 & 11.8 & 11 \\
\hline Musculoskeletal diseases & 2 & 2.2 & 13 & 6.5 & 8.0 & 13 \\
\hline Genitourinary diseases & 0.0 & 0.0 & 3 & 1.5 & 6.4 & 14 \\
\hline Endocrine, blood, immune disorders & 9 & 9.8 & 26 & 13.0 & 5.7 & 15 \\
\hline Skin diseases & 6 & 6.5 & 2 & 1.0 & 1.0 & 22 \\
\hline Total & 92 & 100.0 & 200 & 100.0 & - & - \\
\hline
\end{tabular}


Even though these medicines are considered a priority for research and development in Brazil, recent RENAME versions, from 2012 and 2014, have an insufficient number of selected medicines for neglected diseases when considering the prevalence and severity of some of them 21,22,23.

The list of strategic medicines for the SUS selected 15 out of 26 anti-retroviral medicines present in RENAME 2014. OPL already produce some of them. The Brazilian model for providing antiretroviral medicines has been considered a successful response to the developing AIDS epidemic report. Universal access to these medicines is possible, in part, thanks to the national pharmaceutical companies that produce, since 1995 , generic antiretroviral products 24,25 .

Among noncommunicable diseases, the number of anticancer medicines and those with clinical indication for endocrine and metabolic diseases, obtained from biological sources, such as enzymes, proteins and hormones, represents $14 \%$ of the medicines selected as strategic for the SUS.

There is a disproportional relationship between the number of strategic medicines for the SUS and the burden of disease according to DALY (Figure 1).

Medicines for psychiatric diseases already produced by OPL and selected in the list of strategic medicines for the SUS are intended for the treatment of schizophrenia and depression. With regard to the treatment of schizophrenia, OPL produce two medicines, while the strategic medicines list includes four additional medicines. With the exception of risperidone, all medicines, as described in the guideline treatment for schizophrenia, are either already produced by OPL or were selected as strategic for public production 26 .

Depression is the disease with the greatest DALY among the psychiatric disorders. It is also the leading cause of DALYs, according to the Brazilian Burden of Disease Study from 2008. OPL produce the antidepressants amitriptyline and imipramine, which were included in RENAME 2014, though they have not been included in any other version of RENAME. RENAME 2014 features four medications for depression: amitriptyline, clomipramine, fluoxetine and nortriptyline, yet no medicine for depression was present in the list of strategic medicines for the SUS. This is of interest considering antidepressants are among the priorities for innovation presented in the 2013 report from the World Health Organization (WHO), since it considers there to be gaps in pharmaceutical treatments and serious adverse events in antidepressant treatments 15 .

For cardiovascular diseases, the OPL produce diuretics, antihypertensives and platelet antiaggregates (acetylsalicylic acid). The list of strategic medicines for the SUS selected statins and an anti-hypertensive (captopril), alongside other medicines in RENAME 2014, including other platelet antiaggregates (clopidogrel, abciximab, tirofiban) and antithrombotics (alteplase and tenecteplase).

\section{Figure 1}

Number of strategic medicines for Brazilian Unified National Health System (SUS) and disability adjusted life years (DALY x 10,000 inhabitants).

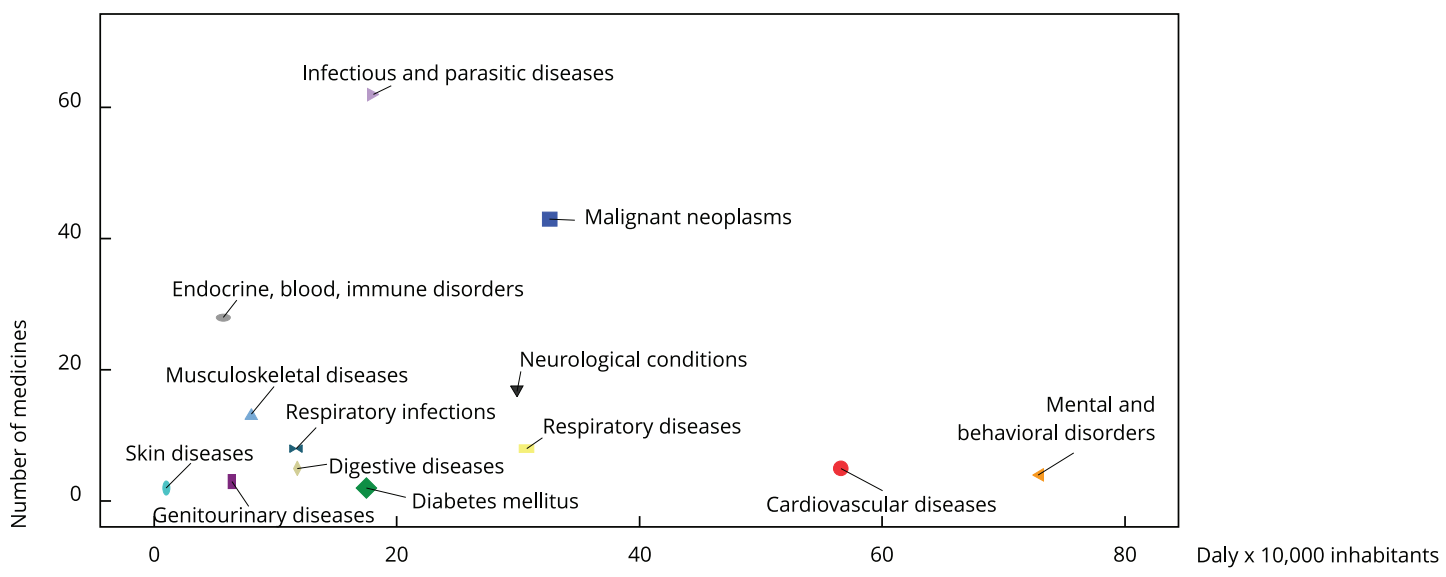


Currently, no OPL produces anticancer medicines, most likely because their production requires a differentiated manufacturing structure 27 . On the other hand, anticancer medicines are the largest number of medicines selected as being strategic for national production.

For chronic respiratory diseases, the increase in medicine number occurred due to the inclusion of salmeterol, formoterol and budesonide in the list of strategic medicines for the SUS. For neurological disorders, OPL produce medicines for epilepsy and Parkinson's disease while the strategic medicines list has selected medicines for Alzheimer's disease and multiple sclerosis.

NHP and regular insulins were considered strategic for the national production of diabetes mellitus, in addition to glibenclamide and metformin, which are already produced by OPL.

A large number of medicines, selected as strategic medicines for the SUS, are derived from biological sources and intended for the treatment of rheumatoid arthritis and endocrine-metabolic diseases.

According to the National Policy of Medicines, the current capacity of the OPL should be used, preferably, to meet the needs of essential medicines 1 and, according to the WHO, the selection of essential medicines must be influenced by national burden of disease studies 16 . In this sense, the selection of strategic medicines for the SUS, in order to subsidize PDP, acts on important causes of the burden of disease, such as cancer, endocrine-metabolic, neurological (e.g., Parkinson's disease, epilepsy, Alzheimer's disease and multiple sclerosis) and musculoskeletal (e.g., rheumatoid arthritis) disorders. Contrarily, medicines for psychiatric disorders and cardiovascular diseases don't seem to have the same importance in this list.

The large number of medicines intended for cancer treatment and from selected biological sources questions whether the current OPL are qualified to absorb these technologies, specifically regarding the production of anticancer medicines. The current structure of the OPL would not support such production, requiring the construction of new facilities and the expansion of existing ones in order to meet the regulatory requirements to produce this type of medicine. Some authors question if the current capacity of public production is able to meet the demands of the Ministry of Health 5,27.

A growing number of new medicines are launched on the market, increasing the demand of patients, health professionals, and even the government 28. Although there are structured mechanisms for evaluating new medicines, presently there is a process of rapid incorporation, at high prices, many subjected to a monopoly situation in Brazil and throughout the world, leading to the continued growth of public spending on pharmaceutical services 5 .

The selection of medicines for national production and the establishment of PDP have the main objective of promoting the development and production of strategic products for the SUS in Brazilian territory, expanding the access of strategic products to the population and reducing the vulnerability of the SUS 7. In this sense, considering the results of this paper some questions deserve to be highlighted.

Initially, it is important to question the selection criteria used in establishing the list of strategic medicines for the SUS. The criteria appear to not be well defined, and the selection of medicines reflects just that.

The selection of strategic medicines for the SUS should also consider the centralized acquisition, or the acquisition as subject of centralization, by the Ministry of Health. Currently only the Strategic Component of Pharmaceutical Services has centralized the acquisition by the Ministry of Health and this centralization features a similar proposal as a way to use the purchasing power of the State and thus stimulate the domestic production of medicines 7,29,30. However, OPL continue to be public market-dependent, and may remain vulnerable to changes in pharmaceutical policies, in the methods of acquisition, in guidelines, and in the government 31 .

There are monopolies and oligopolies within therapeutic classes and subclasses in the Brazilian pharmaceutical market. Pharmaceutical companies specialize themselves because of the variety and complexity of processes and related knowledge as well as the peculiarities of each market segment $32,33,34$. Thus, it can be said that the competition and differentiation of the product takes place within therapeutic classes and not between industries as a whole 35 . This highlights some challenges for OPL in the SUS, including: which groups of medicines really are strategic, what is the strategy to define the portfolios of OPL and how the division of production between the labs should occur. It may be of importance for OPL to consider that, rather than producing new medicines, they should devote resources instead to the production of medicines that already exist in their portfolios, but in new dosage forms relevant to specific populations, such as the paediatric population. 
The OPL management is another aspect to be considered. Although these laboratories have been upgraded and now have appropriate technical conditions, their commercial and managerial development did not advance. In 2005, the Ministry of Health established the Brazilian Network of Public Medicines Production with the purpose of coordinating the public laboratories. It seems there is difficulty either in reconciling the public production with the new industrial policy, or in recognizing the effect of strategic roles for Brazilian Medicines Policy and Pharmaceutical Services 31,36.

As a final point, it is worth considering the low investment in research and development, which reflects on the implementation of the current technology policy transfer through the PDP. OPL do not receive sufficient investment in research to enable replication or even improvement of patented products at a laboratory scale 3 . It seems that it is hard to provide sustainable access due to changes in the Brazilian Industrial Policy such as the PDP. Assuming that access to medicines is not restricted to their availability, it can be alternatively affected by other measurable dimensions, such as accessibility, adequacy, affordability, capacity and acceptability 34,37. According to Frost \& Reich 38, the acquisitive capacity dimension should also consider the economic capacity of the government and non-governmental agencies to cover the costs of medicine acquisition. In this sense, one can wonder if the medicines produced under the new Brazilian Industrial Policy will be affordable. Additionally, ensuring that the actions of the Health Economic-Industrial Complex do not consider the SUS health services as an entity with the purchase of technologies as its sole purpose, while not discouraging government initiatives for price adjustment, comparable to the negotiation of prices and technology in a monopoly situation, is also important 5 .

\section{Final considerations}

The present study sought to examine to what extent the public production of medicines relates to the population's health needs, identified by the 2008 Brazilian Burden of Disease Study.

Some of the medicines selected as strategic for national production are manufactured by OPL, mainly among the strategic components of medicines of pharmaceutical services. The selection of medicines for neglected diseases in the list of strategic medicines for the SUS is extremely important, because the production of these medicines is often not of interest to the private industry, especially those from developed countries. The inclusion of these medicines on the list of strategic medicines for the SUS has previously benefited public health and the treatment of these diseases.

There are strategic anticancer medicines derived from biological sources selected in large scale for national production. Currently, OPL do not manufacture medicines of this nature and future production will require investment in industrial lands for processing and health standard adaptations.

The limitations of this study relate to the application of the results of the Brazilian Burden of Disease Study from 2008 and the use of the data within OPL portfolios. Initially there was some difficulty in the classification of medicines according to the cause of DALY, mainly for medicines with more than one clinical indication, such as antibiotics. Therefore, in seeking to improve the classification, various sources and a specialist have been consulted. Furthermore, the absence of dosage form in the list of medicines considered strategic for public production has limited the analysis by medicine. The use of OPL electronic sites as data source is a limitation because the sites change drastically and can be outdated.

The present study raised many questions about the public production of medicines, especially considering the current industrial policy. It is necessary to further discuss the criteria for priority medicines for the SUS. Furthermore, discussion is required on the role of OPL to ensure access to medicines and the sustainability of the health system, since actions taken by the Health EconomicIndustrial Complex are focused on producing high-cost products.

The analysis, relating the burden of disease in Brazil, the OPL medicines portfolios and the strategic medicines for the SUS, performed by disease and therapeutic grouping, is an important task to be accomplished in the future.

Some future studies can be suggested, in addition to contributing to the defining the criteria for the selection of strategic medicines for the SUS, this includes the study of: (1) pharmaceutical gaps, including pharmaceutical treatments for a condition that will soon become ineffective (e.g. due to resistance), delivery mechanisms or formulations not appropriate for a target patient group, or 
effective medicine that either does not exist or is not sufficiently effective (e.g. lack of basic scientific knowledge or lack of financial incentive due to market failure); (2) dependence on importation of active pharmaceutical ingredients and; (3) burden of disease, cost-effectiveness of investing in new technologies, the necessary financial investments and the sustainability of long term production.

\section{Contributors}

T. A. Figueiredo contributed to the design of the central idea of the research work, with data collection, database creation, data analysis and with the writing of this paper. J. M. A. Schramm participated in the design of the central idea of the research work in addition to writing this paper and proofreading its final version. V. L. E. Pepe collaborated in the design of the central idea of the research work, with data analysis and with the writing this paper.

\section{References}

1. Ministério da Saúde. Portaria no 3.916, de 10 de novembro de 1998. Aprova a Política Nacional de Medicamentos. Diário Oficial da União 1998; 11 nov.

2. Magalhães JL. Estratégia governamental para internalização de fármacos \& medicamentos em doenças negligenciadas [Doctoral Dissertation]. Rio de Janeiro: Escola de Química, Universidade Federal do Rio de Janeiro; 2010.

3. Oliveira E. Política de produção pública de medicamentos no Brasil: o caso do Laboratório Farmacêutico do Estado de Pernambuco (LAFEPE) [Doctoral Dissertation]. Rio de Janeiro: Escola Nacional de Saúde Pública Sergio Arouca, Fundação Oswaldo Cruz; 2007. 
4. Bermudez JAZ. Acceso a medicamentos: derecho fundamental, papel del Estado. Rio de Janeiro: Escola Nacional de Saúde Pública, Fundação Oswaldo Cruz; 2004.

5. Hasenclever L. Reflexo das políticas industriais e tecnológicas de saúde brasileiras na produção local e no fornecimento ao SUS. http:// www.ie.ufrj.br/images/pesquisa/pesquisa/tex tos_sem_peq/texto0104.pdf (accessed on 20/ Dez/2015).

6. Machado CV, Baptista TWF, Lima LD. O planejamento nacional da política de saúde no Brasil: estratégias e instrumentos nos anos 2000. Ciênc Saúde Coletiva 2010; 15:757-72.

7. Ministério da Saúde. Portaria no 2.531, de 12 de novembro de 2014. Redefine as diretrizes e os critérios para a definição da lista de produtos estratégicos para o Sistema Único de Saúde (SUS) e o estabelecimento das Parcerias para o Desenvolvimento Produtivo (PDP) e disciplina os respectivos processos de submissão, instrução, decisão, transferência e absorção de tecnologia, aquisição de produtos estratégicos para o SUS no âmbito das PDP e o respectivo monitoramento e avaliação. Diário Oficial da União 2014; 13 nov.

8. Ministério da Saúde. Portaria no 837, de 18 de abril de 2012. Define as diretrizes e os critérios para o estabelecimento das Parcerias para o Desenvolvimento Produtivo (PDP). Diário Oficial da União 2012; 19 abr.

9. Begg SJ, Vos T, Barker B, Stanley L, Lopez AD. Burden of disease and injury in Australia in the new millennium: measuring health loss from diseases, injuries and risk factors. Med J Aust 2008; 188:36-40.

10. Dantés EA. La carga de la enfermedad en países de América Latina. Salud Pública Méx 2011; 53 Suppl:s72-7.

11. McKenna MT, Michaud CM, Murray CJ, Marks JS. Assessing the burden of disease in the United States using disability-adjusted life years. Am J Prev Med 2005; 28:415-23.

12. Norman R, Matzopoulos R, Groenewald P, Bradshaw D. The high burden of injuries in South Africa. Bull World Health Organ 2007; 85:695-702.

13. Schopper D, Pereira J, Torres A, Cuende N, Alonso M, Baylin A, et al. Estimating the burden of disease in one Swiss canton: what do disability adjusted life years (DALY) tell us? Int J Epidemiol 2000; 29:871-7.
14. Resnik DB. Setting biomedical research priorities: justice, science, and public participation. Kennedy Inst Ethics J 2001; 11:181-204.

15. Kaplan W, Wirzt VJ, Mantel-Teeuwisse A, Stolk P, Duthey B, Laing R. Priority medicines for Europe and the world. Geneva: World Health Organization; 2013.

16. World Health Organization. The world medicines situation 2011: selection of essential medicines. 3rd Ed. Geneva: World Health Organization; 2011.

17. Leite IC, Valente JG, Schramm JMDA, Oliveira AFD, Mota JCD, Costa MDFS, et al. Relatório final do Projeto Carga de Doença do Brasil 2008. Rio de Janeiro: Escola Nacional de Saúde Pública Sergio Arouca, Fundação Oswaldo Cruz; 2013.

18. Capellà D, Laporte JR. Métodos aplicados en estudios descriptivos de utilización de medicamentos. In: Laporte JR, Tognoni G, editors. Principios de epidemiología del medicamento. Barcelona: Fundació Institut Català de Farmacologia; 2008. p. 1-15.

19. Comissão Nacional de Incorporação de Tecnologias. Penicilina benzatina para prevenção da sífilis congênita durante a gravidez. Brasília: Ministério da Saúde; 2015. (Relatório de Recomendação, 150).

20. Conselho Nacional de Secretários de Saúde. Apresentação das dificuldades enfrentadas pelas Secretarias Estaduais de Saúde na aquisição de medicamentos. http://www.conass.org. br/NT\%2015\%20-\%202014\%20-\%20atualiza da\%20out.\%20DIFICULDADES\%20NA\%20 AQUISIC\%CC\%A7A\%CC\%83O\%20DE\%20 MEDICAMENTOS\%20NAS\%20SES.pdf (accessed on 22/Sep/2015).

21. Yamey G. Public sector must develop drugs for neglected diseases. BMJ 2002; 324:698.

22. Morel CM. Inovação em saúde e doenças negligenciadas. Cad Saúde Pública 2006; 22:1522-3.

23. Beyrer C. Neglected diseases, civil conflicts, and the right to health. Lancet 2007; 370:619-27.

24. Scheffer MC. Aids, tecnologia e acesso sustentável a medicamentos: a incorporação dos anti-retrovirais no Sistema Único de Saúde. São Paulo: Universidade de São Paulo; 2008. 
25. Conselho Nacional de Saúde. Resolução no 352, de 11 de agosto de 2005. Delibera sobre a emissão de licenças compulsórias dos medicamentos Efavirenz, Lopinavir e Tenofovir, bem como de outros anti-retrovirais patenteados e a fabricação local dos medicamentos. http:// conselho.saude.gov.br/resolucoes/reso_05. htm (accessed on 22/Sep/2015).

26. Ministério da Saúde. Portaria no 364, de 09 de abril de 2013. Aprova o protocolo clínico e diretrizes terapêuticas - esquizofrenia. Diário Oficial da União 2013; 10 abr.

27. Agência Nacional de Vigilância Sanitária. Resolução RDC no 17, de 16 de abril de 2010. Dispõe sobre as boas práticas de fabricação de medicamentos. Diário Oficial da União 2010; $17 \mathrm{abr}$.

28. Conselho Nacional de Secretários de Saúde. Ciência e tecnologia em saúde. Brasília: Conselho Nacional de Secretários de Saúde, 2011. (Coleção Para Entender a Gestão do SUS, 11).

29. Rezende KS. As parcerias para o desenvolvimento produtivo e estímulo à inovação em instituições farmacêuticas públicas e privadas [Masters Thesis]. Rio de Janeiro: Escola Nacional de Saúde Pública Sergio Arouca, Fundação Oswaldo Cruz; 2013.

30. Pimentel VM. Parcerias de desenvolvimento produtivo vinculadas ao Complexo Industrial da Saúde: um estudo sobre os avanços e o papel de cada agente de saúde na inovação e estruturação do Parque Farmacêutico Nacional [Masters Thesis]. Belo Horizonte: Universidade Federal de Minas Gerais; 2012.

31. Oliveira EA, Labra ME, Bermudez J. A produção pública de medicamentos no Brasil: uma visão geral. Cad Saúde Pública 2006; 22:2379-89.

32. Gadelha CAG, Quental C, Fialho BC. Saúde e inovação: uma abordagem sistêmica das indústrias da saúde. Cad Saúde Pública 2003; 19:47-59.
33. Godoy MR. A indústria farmacêutica brasileira na década de 90. In: Anais do XXVI ENANPAD. http://www.anpad.org.br/admin/ pdf/enanpad2002-pop-1421.pdf (accessed on 22/Sep/2015).

34. Luiza VL. Acesso a medicamentos essenciais no Estado do Rio de Janeiro [Doctoral Dissertation]. Rio de Janeiro: Escola Nacional de Saúde Pública, Fundação Oswaldo Cruz; 2003.

35. Bastos VD. Inovação farmacêutica: padrão setorial e perspectivas para o caso brasileiro. Rio de Janeiro: Banco Nacional do Desenvolvimento Econômico e Social; 2005.

36. Hasenclever L, Fialho BC, Oliveira MA, Oliveira EA, Silva HF, Bermudez JAZ. Diagnóstico e papel dos Laboratórios Públicos na capacitação tecnológica e atividades de P\&D da indústria farmacêutica brasileira. In: Buss PM, Carvalheiro JR, Casas CPR, organizadores. Medicamentos no Brasil: inovação e acesso. Rio de Janeiro: Editora Fiocruz; 2008. p. 199-231.

37. Penchansky DBA, Thomas JW. The concept of acess: definition and relationship to consumer satisfaction. Med Care 1981; 19:127-40.

38. Frost LJ, Reich MR. Access: how do good health technologies get to poor people in poor countries? Cambridge: Harvard Center for Population and Development Studies; 2008. 


\section{Resumo}

A produção pública de medicamentos no Brasil pelos Laboratórios Farmacêuticos Oficiais (LFO) retornou a ser alvo de incentivo e as Parcerias de Desenvolvimento Produtivo são um dos instrumentos adotados para a produção de medicamentos estratégicos para o Sistema Único de Saúde (SUS). Tendo em vista que os estudos de carga de doença vêm sendo utilizados como ferramenta para definição de medicamentos prioritários e essenciais, este artigo relaciona os portfólios dos LFO e a lista de medicamentos estratégicos para o SUS com a carga de doença no Brasil 2008. Dos 205 medicamentos estratégicos para o SUS e 111 dos portfolios, 73\% e 89\% estão na RENAME 2014. Alguns medicamentos estratégicos para o SUS já são produzidos pelos $L F O$ e destaca-se a seleção de medicamentos para câncer e oriundos de rota biológica. O presente estudo contribui para a discussão da produção pública de medicamentos frente a atual politica industrial e destaca a necessária definição de medicamentos prioritários e o papel dos laboratórios farmacêuticos oficiais na garantia de seu acesso.

Carga da Doença; Anos de Vida Perdidos por Incapacidade; Indústria Farmacêutica; Assistência Farmacêutica

\section{Resumen}

La producción pública de medicamentos en Brasil por los Laboratorios Farmacéuticos Oficiales (LFO) volvió a ser objetivo de incentivos, así como las Colaboraciones de Desarrollo Productivo que son uno de los instrumentos adoptados para la producción de medicamentos estratégicos para el Sistema Único de Salud (SUS). Teniendo en vista que los estudios de carga de enfermedad está siendo utilizados como herramienta para la definición de medicamentos prioritarios y esenciales, este artículo relaciona los portafolios de los LFO y la lista de medicamentos estratégicos para el SUS con la carga de enfermedad en Brasil 2008. De los 205 medicamentos estratégicos para el SUS y 111 de los portafolios, $73 \%$ y $89 \%$ están en la RENAME 2014. Algunos medicamentos estratégicos para el SUS y a son producidos por los LFO y se destaca la selección de medicamentos para cáncer y los provenientes de ruta biológica. El presente estudio contribuye a la discusión de la producción pública de medicamentos, frente a la actual politica industrial, y destaca la necesaria definición de medicamentos prioritarios y el papel de los laboratorios farmacéuticos oficiales en la garantía a su acceso.

Carga de la Enfermedad; Años de Vida Perdidos por Incapacidad; Industria Farmacéutica;

Servicios Farmacéuticos
Submitted on $30 /$ Oct $/ 2015$

Final version resubmitted on 31/Aug/2016

Approved on 08/Sep/2016 